Review article

Economics of Agriculture 1/2018 UDC: 502/504:351.765(497.11) doi:10.5937/ekoPolj1801293P

\title{
ENVIRONMENT AND LEGAL PROTECTION OF ANIMALS IN THE REPUBLIC OF SERBIA
}

\author{
Zdravko Petrović, , Jović Vojislav², Manojlović Dragan ${ }^{3}$
}

\begin{abstract}
Summary
The aim of this study was to investigate the application of scientific methods of animal protection in the legal legislation of the Republic of Serbia, through assaults on the environment. Apart from the introductory definition of the subject matter, normative developments of all legal norms protecting the animal rights have been described as well. From the results of the research which were obtained through the application of legal and dogmatic scientific methods, content analysis, quantitative and qualitative description and correlation, it can be concluded on the grounds of several findings as follows: contemporary legal theory and legislation of the Republic of Serbia do not deny the protection of animal rights; within the framework of codification of the Serbian substantive criminal law which was performed in 2005, the criminal and legal norms providing legal animal protection have not gain their importance yet, primarily since they are classified under the environmental offences and not under an independent chapter of the criminal law which will be justified. The findings indicate that the loss of crime in the offences against life, physical integrity and welfare of animals make more than a half in the total number of criminal charges against the suspect charged with committing offences against animals.
\end{abstract}

Key words: ecological, animal protection, criminal code, sanction and offender.

JEL: $K 14, K 140$

\section{Introduction}

The subject matter of the legal protection of animals is the animal welfare as a general value which can be explained from several different aspects. Namely, a change in human consciousness over the last century has contributed, at the first place, that animals have

1 Zdravko Petrović, PhD., Full professor, Faculty of Law, Bulevar umetnosti Street no. 29, 11070 Novi Beograd, Serbia, Phone:+381 63575 880, E-mail:zpetrovic@megatrend.edu.rs

2 Vojislav Jović, PhD., Assistant Professor, Faculty of Law, Bulevar umetnosti Street no. 29, Novi Beograd, Serbia, Phone: +381 6313339 99, E-mail: vjovicbg@gmail.com

3 Dragan Manojlović. PhD., Associate Professor, Faculty of Law, Bulevar umetnosti Street no. 29, Novi Beograd, Serbia, Phone:+ 3816432219 26, E-mail:savaskela@gmail.com

EP 2018 (65) 1 (293-305) 
being treated as living beings not as goods. That is the main reason why the animal welfare is highlighted as a protective value, and thus, it is necessary to regulate it by law as well as to explore it scientifically.

The most important feature in defining and regulating the animal welfare (Mason, Latham, 2004) is based upon the scientific facts that animals as sentient beings are able to feel pain, fear, suffering, stress as well as that such conditions can cause panic, anxiety, insecurity, discomfort, whereas, on the other hand, they can exhibit joy, happiness, satisfaction, feelings of safety, etc.

There are different definitions of the term "animal welfare", although they all refer to the key elements of welfare such as: quality of life, mental and physical satisfaction; conditions for adapting to the environment; respecting their nature (Rollin, 1993). Some authors quote that animal welfare refers primarily to the state in which animals accomplish complete mental and physical health as well as harmony with their environment (Carenzi, Verga, 2007).

The term animal welfare is usually used in the context of those animals whose survival is related to the man. Acknowledging this fact, the theorists base the definition of welfare upon the so-called Five Freedoms Concept (Webster, 2006), which covers: Freedom from Hunger and Thirst; Freedom from Pain, Injury or Disease; Freedom from Fear and Distress; Freedom from Discomfort- which means an appropriate environment including shelter and a comfortable resting area; Freedom to Express their Natural Behaviour and Company of the animal's own or compatible kind.

Although, on one hand, the animal welfare is classified as one of the proclaimed values which are responsible for the overall well-being of animals, the question is whether it is certain to expect a complete fulfilment of all five freedoms which makes the framework for defining welfare in Serbia. On the other hand, there are researches which indicate that animal welfare is not always and entirely crucial for accomplishing certain physical and mental abilities, so, therefore, when evaluating the welfare criteria it is necessary to be cautious, particularly when the productive and reproductive readiness of animals is the issue (Broom, 1991).

\section{Methodology and Data Sources}

The sources of data (Statistical Office of the Republic of Serbia, Bulletin number 588, ISSN 0354-3641, 2014.) titled "Criminal charges" on the crimes against animals committed by the adult persons in the Republic of Serbia, were obtained on the basis of the research which was conducted using the Questionnaire CK-1" The Questionnaire for an adult against whom the legal proceeding was completed". The data on the crimes of the accused and convicted adults were obtained on the grounds of the research which was conducted using Questionnaire CK-2 "The Questionnaire for the accused and convicted adult against whom the final criminal proceedings was completed".

The instruments of the research have encompassed all the adult persons in the Republic of Serbia against whom there was a reasonable suspicion of having committed an offence 
against animals and against whom the criminal charges were filed at the competent public prosecutor's office as well as those against whom statutory proceeding was conducted and completed.The term adult offender relates to the offender who was 18 years old at the time crime was committed.

The term type of decision (Questionnaire CK-1) implies the decision of the public prosecutor with which the legal proceedings were completed. The person reported relates to an adult person against whom criminal proceeding was conducted and lawsuit was filed due to the reasonable doubt that the person committed the offence. "The accused" is an adult person against whom indictment, proposition of the indictment or plaintiff was brought before the court. The convicted person refers to an adult person who was found guilty and against whom criminal sanctions were imposed. "Criminal offence" is the offence which has been prescribed by the law as the criminal act which is contrary to the law or committed against law. The expression "animal"in legal sense refers to any vertebrate able to feel pain, suffering, fear and stress (Law on Animal Welfare ("Official Gazette of the Republic of Serbia" No. 41/2009). When using the word "animal" in the scientific terms, it implies a large group of multicellular, eukaryotes and heterotrophic organisms classified in biology as the Animalia Kingdom (Nielsen, 2001). In this paper work the term "sanction" relates to a part of legal norm which is known as secondary disposition (Encyclopaedia of the social sciences, Macmillan Co., New York, Volume XIII, 1933, 531. 30).

\section{Animal protection in constitutional and administrative law}

The Constitution of the Republic of Serbia in its provisions does not explicitly stipulate the animal protection; however it is implied within the context of environmental protection, through an already proclaimed right of everyone to the healthy environment, or, in other words, through an obligation to protect and improve the environment (The Constitution of the Republic of Serbia („Official Gazette of Republic Serbia“, no. 98/2006). The protection of animals in administrative law (The Law on Environmental Protection (,Official Gazette of Republic Serbia “, no. 135/2004, 36/2009, 36/2009 - Dr. Law 72/2009 - Dr. Law and 43/2011 - Decision of the Constitutional Court) is generally regulated by the Law on Environmental Protection (The Animal Welfare Act (,Official Gazette of Republic Serbia “, no. 41/2009) within the water protection, protection of flora and fauna as well as within the preventive measures of the environmental protection (planning, construction and strategic assessment of the influences on the environment). The concrete administrative and legal protection of animals (Directive 86/609/EEC - J. Eur. Commun. Legal Spec., 1986, Reconciliation of Legal and Administrative Regulations of the Member Countries for the Protection of Animals used for Studies ... Directive 86/609/EEC - J. Eur. Commun. Legal Spec., 1986) is regulated by the Animal Welfare Act (Regulation on conditions for animal welfare in terms of space for animals, premises and equipment in the facilities where they are kept and bred animals placed on the market for production purposes, the method of keeping, breeding and transport of certain animal species and categories, as well as the keeping of records 
of animals („Official Gazette of Republic Serbia“, no. 6/2010 and 57/2014) within the framework of the standardized rights, obligations and responsibilities of legal and natural persons as well as entrepreneurs. The legislator classifies all animals to which the welfare refers into seven categories: the animals which are used in production, animals used for scientific, biomedical and educational purposes, animals used for exhibitions, competitions, performances and other forms of public events, animals for work and official animals, pets, abandoned and lost animals, wildlife in captivity.

General legal protection of animal welfare encompasses the right of all legal and natural persons or entrepreneurs to keep and breed animals in accordance with the prescribed conditions, their obligation to take care of the animals and their duty to treat the animals with commitment of a good owner/host in the sense of providing conditions for keeping the animals and taking care of them in accordance with the specificities of that animal's kind, gender and age and its physical and biological characteristics.

Treatment with commitment of a good owner/host means providing conditions which satisfy the animal needs such as: sufficient quantities of good-quality water and food, having enough space for movement, nutrition and rest, shelter, microclimate and hygienic living conditions, presence and company of the animal's own kind, preserving the animal's physical, physiological and genetic integrity by undertaking and conducting preventive, diagnostic, hygienic, therapeutic and other measures in order to preserve the animal health and prevent injuries, illnesses, stress, pain, suffering, fear and death of an animal. The general legal framework also encompasses a ban on executing any kind of intervention on animals which changes their identity, disguises physical deficiencies or amputates certain body parts. General legal protection of the animal welfare includes the principle of humane slaughter of animals (Blessing, Marshall, Balcombe, 2010) entailing that animals can be deprived of life in when they used for human consumption, when injured or terminally ill, or, when, due to the old age or some infectious disease some of their vital functions have stopped.

Specific legal protection of animal welfare (Camm, Bowles, 2000) encompasses the protection measures in the field of keeping, breeding, selling, transporting, slaughtering and conducting experiments including animals. It relates to the facilities used for keeping and breeding the animals, the ways of transport and registering the carriers, application of humane principles of slaughtering and the ways in which experiments including animals are preformed. In accordance with the stipulated standards, the accommodation standards relate, inter alia, to the fulfilment of the microclimate and hygienic conditions as well as to the conditions which apply to the physical and biological animal needs according to its kind, gender and age. In addition, taking care of the animals, according to the legal provisions, must be performed by a certain number of the trained persons who, together with the owner (Feinberg, 2012), or animal keeper, are responsible for the prevention of technopathy - a disorder which includes disturbance of animal's health caused by some errors made in the process of animal keeping-, physicopathy, (illnesses and injuries) which is manifested in reproduction process, and etiopathy (behavioural disorders). The restrictive legal provision prescribes certain regulations 
which relate, among the other things, to transport of pregnant and new-born animals, their protection from weather and climate conditions, and fulfilment of some general and specific requirements regarding the means of transportation of the animals as well as necessary training level of carriers in the field of animal welfare. The experiments including animals (McGrath, Drummond, McLachlan, Kilkenny, Wainwright, 2010) can be performed only in cases regulated by law, particularly when they refer to: the prevention of a disease in humans and animals, testing certain drugs, substances and products as well as in cases of diagnosing and treating diseases in humans and animals, in scientific research (Baumans, 2004), educational and vocational training and forensic medical testing (McGrath, Drummond, McLachlan, Kilkenny, Wainwright, 2010).

Experiments including animals are explicitly banned when they are used for the purposes of testing weapons and war equipment as well as when examining the impacts of radiation, testing cosmetics and disinfectants products, tobacco and alcohol drinks and products designed to increase muscles mass. Animal welfare is regulated by subordinate regulations among which the Rulebook on animal welfare conditions which refer to the space for animals, facilities in which the animals are kept, bred and sold for the production purposes as well as the equipment used in these facilities, the ways of keeping, breeding and selling certain animal species and categories as well as keeping the records of them (Feinberg, 2012).

The Rulebook prescribes accurately the standards for space, facilities and equipment thus preventing unnecessary pain, injuries, suffering and disease of animals. These standards particularly refer to the daily control of the accomplished protection and welfare, the isolation of sick animals in separate facilities, including weather and climate conditions as well as lightning and noise conditions. In terms of keeping, breeding and selling certain species and categories of animals, the Rulebook stipulates, among other things, the conditions according to the age structure when keeping young population of animals in the group, selecting the necessary floor space which depends upon the animal body weight. In the addition, highly important standards relate to enabling social connections among the individually housed animals including a possibility of visual and physical contact.

\section{Criminal law protection of animals}

The Animal Protection in the Republic of Serbia has obtained a qualitative legal form with the codification of the substantive criminal legislation from 2005 and, subsequently, within the framework of the amendments in the field of environmental legislation. Namely, the criminal protection of animals has been more concretely specified within the unique Chapter of the Criminal Code (The Criminal Code („Official Gazette of RS“, no. 85/2005, 88/2005, 107/2005, 72/2009, 111/2009, 121/2012 and 104/2013) which refers to the ecological offences and environmental offences. The seven offences out of the eighteen criminal offences laid down by this Chapter refer to the direct protection of animals, whereas the animals are protected indirectly with incrimination in five criminal offences and within the qualified forms of the criminal offence. The indirect 
criminal law protection of the animals includes incrimination which refers to the: animal killing and abuse, transmission of infectious diseases, providing veterinarian treatment, production of drugs for animal treatment, contamination of water and food for animals, illegal hunting and fishing. Killing and animal abuse represent the most difficult form of incrimination whose basic qualification has been reformulated by the amendments to the Criminal Code from 2009. Thus, animal abuse has been determined as a wider form of incrimination comparing to the previous incrimination of animal cruelty and a new form of incrimination, which relate to organizing animal fighting, has been introduced. According to the explanation of certain authors, "abuse" as a broader expression than torturing or brutality and cruelty, sets up a wider legal framework within which numerous incriminations, including neglect, can be sanctioned (Beirne, 2004). The restrictive legal interpretation defines "abuse" as causing injury and torture, implying that "injury" is usually manifested as physical trauma, while "torture" can be explained as any act by which pain and suffering, whether physical or mental, are intentionally inflicted. The first qualified form of the criminal offence is determined by the consequence and the object of legal protection, or when a larger number of animals is killed or tortured or the offence was committed against the animal belonging to a specially protected species (Ordinance on the proclamation and protection of strictly protected and protected wild species of plants, animals and fungi (,Official Gazette of Republic Serbia “, No. 5/2010), Stock listed in Annex I and Annex II. 20). The second qualified form of the criminal offence encompasses the offences of organizing, financing or enabling animal fighting motivated by greed or financial gain by making bets on animals fights (Lazarević, 2006). The farm animals in animal husbandry are the object of criminal law protection from the offence of transmitting infectious diseases among animals. The basic form of incrimination encompasses the failure to act according to the regulations (Petrović, Simić, 1985) decisions or orders of the competent body during the epidemic of an animal disease in the field of cattle breading. In the addition, if the consequence of this situation is death of an animal or some other occurrence causing serious damage, it represents a form of the criminal offence.

Veterinary malpractice (Huss Rebecca, 2004) implies an incrimination which refers to the prescription of an obviously incorrect medication/drug, mistreatment of an animal, or some other form of professional negligence in the treatment of animals (Srzentić, Lazarević, Đorđević, Stajić, Kraus, 1991) which caused death of an animal or any other significant harm. Manufacturing of harmful drugs and medications in animal medical care encompasses the incriminations which relate to manufacturing drugs for animal treatment and prevention of infectious diseases for selling while having evidences of their harmful effect on life and health of animals.

The sale should be interpreted in terms of all basic and supporting business activities intended for purchase and sales of goods and services (Trade Law („Official Gazette of Republic Serbia“, No. 53/2010 and 10/2013). The qualified form of incrimination exists in case when a certain harmful device caused a fatal consequence for animal or caused some other significant damage. The pollution of water and food for feeding 
and watering the animals entails the activity which refers to the use of any harmful substance with which the feed or water are polluted.

The basic forms of criminal offence include causing danger of jeopardising health and life of animals due to the use of harmful substances. While this represents an abstract consequence, the occurrence of death or some other serious physical damage of an animal represents a manifestation of the qualified type of incrimination.

Illegal hunting covers various types of incrimination which, depending on the time and the place of the offence, exists if the game (wildlife) is being hunt during the closed season, in the area wherein the hunting is forbidden or done without permission in the hunting property belonging to a third party. According to the provisions of the Law on Hunting the game/ wildlife represents a certain species of wild mammals and birds determined by law (Law on Hunting Law („Official Gazette of Republic Serbia“, No. 18/2010). The incrimination encompasses killing, wounding and capturing alive game as well as when the means for mass destruction are used in hunting.

The object of protection in the basic form of the offence is any type of wildlife/game, whereas in the case of qualified incrimination the large game or the game whose hunting is forbidden is the protection object. The elements of the criminal offence of illegal fishing according to the time and place of crime exist when fishing is preformed during the closed season and in the waters in which hunting is prohibited. In the addition, the way of execution as an incrimination type encompasses hunting with explosives, electricity, poison, sedative substances or performing any other form which is harmful for the reproduction of animals or responsible for mass destruction of animals.

In the context of penal policy for the above-analyzed criminal offences the legislator has issued the following sanctions: when committed in their basic form the least severe sanction prescribed is the alternative fine or six months sentence. In the addition as the most severe sanction is also alternative fine or up to two years prison sentence. For the offence which is qualified as more difficult the mildest sanction is an alternative fine or up to three years prison sentence, or cumulative sentence from three months to three years and fine as the most severe sanction.

\section{The results and discusion}

The empirical research covers the period from 2010 to 2015 and through the application of statistical method as well as quantitative and qualitative analysis methods and correlation, it reports the research findings on factual situation in the criminal law protection of animals in the Republic of Serbia.

When analyzing and discussing the findings and results of the research from Table 1, we find out that since being suspected of taking part in and committing offences against animals, 1454 adult persons were reported by filling criminal charges. Of this number 371 adult persons were accused, whereas 176 of the accused were found quilt by the verdict of the court. By applying the correlation method, the finding which shows that 
out of the total number of the reported adult persons for the criminal offences against animals, 25\% persons were accused, whereas $12 \%$ were convicted. The finding resulting from Table 1 indicates that the loss of crime is in correlation with the number of the reported adult persons suspected for conducting offences against animals and the number of those convicted for committing offences against animals in the territory of the Republic of Serbia and is at the level of $88 \%$.

Table 1. The finding on correlation between the numbers of the adult persons reported, accused and convicted for committing all criminal offences against animals

\begin{tabular}{|c|c|c|c|c|c|c|}
\hline \multirow{2}{*}{ Sample of research } & \multicolumn{6}{|c|}{ Finding from the sample of research } \\
\cline { 2 - 8 } & \multicolumn{6}{|c|}{ Years of the sampled sample } \\
\cline { 2 - 7 } & $\mathbf{2 0 1 0}$ & $\mathbf{2 0 1 1}$ & $\mathbf{2 0 1 2}$ & $\mathbf{2 0 1 3}$ & $\mathbf{2 0 1 4}$ & $\mathbf{2 0 1 5}$ \\
\hline Number of the persons reported & 123 & 196 & 178 & 165 & 342 & 454 \\
\hline Number of the accused & 28 & 38 & 43 & 57 & 112 & 93 \\
\hline Number of the convicted & 22 & 27 & 23 & 30 & 16 & 58 \\
\hline
\end{tabular}

Source: Bilten broj 578, 588, 603, 617 Republički zavod za statistiku, Beograd, Republika Srbija. ISSN 0354-3641.(eg.1. Bulletin No. 578, 588, 603, 617. The Republic Statistical Office).

The results of the research in Table 1 show that the number of the adult persons against whom the public prosecutor has dismissed criminal charges since there was not enough elements for starting the procedure by placing demands for investigation is at the level of $73 \%$ in the total level of the reported adult persons who were suspected for committing crimes against animals in Serbia.

Table 2. The finding on correlation from the sample of the persons who have been reported to have committed the criminal offence of animal killing and abuse

\begin{tabular}{|c|c|c|c|c|c|c|}
\hline \multirow{2}{*}{ Sample of research } & \multicolumn{6}{|c|}{ Finding from the sample of research } \\
\cline { 2 - 8 } & \multicolumn{6}{|c|}{ Years of the sampled sample } \\
\cline { 2 - 7 } & $\mathbf{2 0 1 0}$ & $\mathbf{2 0 1 1}$ & $\mathbf{2 0 1 2}$ & $\mathbf{2 0 1 3}$ & $\mathbf{2 0 1 4}$ & $\mathbf{2 0 1 5}$ \\
\hline Number of the persons reported & 123 & 196 & 178 & 165 & 200 & 205 \\
\hline Number of the accused & 28 & 38 & 43 & 57 & 36 & 32 \\
\hline Number of the convicted & 22 & 27 & 23 & 30 & 9 & 23 \\
\hline
\end{tabular}

Souces: Bilten broj 578, 588, 603, 617 Republički zavod za statistiku, Beograd, Republika Srbija. ISSN 0354-3641.(eg.l. Bulletin No. 578, 588, 603, 617. The Republic Statistical Office).

The result of the research from the Table 2 shows that out of the total number of the reported adult persons for whom there was a grounded suspicion of taking part in committing the offence of killing and abusing animals $22 \%$ were accused, while $13 \%$ of them were convicted. When comparing the results obtained from the Table 3 between number of the adult persons who were reported and convicted in the Republic of Serbia, it can be noticed that there is a particularly high percentage of the loss of crime (Sutherlandu, Cressey, Luckenbill, 2001) in the case of criminal acts of killing and abusing the animals and is at the level of $87,00 \%$. 
On the grounds of results from the Table 3 we conclude that out of the total number of the adult persons who were convicted for the criminal offences against animals, the prison sentence was imposed against 89 persons or $16 \%$ with regard to the number of the adult persons who were suspected for committing the offences against animals. Based

Table 3. The quantitative finding on the number of the persons who were convicted for committing the crime against animals (the number of prison sentences)

\begin{tabular}{|c|c|c|c|c|c|c|}
\hline \multirow{2}{*}{ Sample of research } & \multicolumn{6}{|c|}{ Finding from the sample of research } \\
\cline { 2 - 7 } & \multicolumn{5}{|c|}{ Years the sampled sample } \\
\cline { 2 - 7 } & $\mathbf{2 0 1 0}$ & $\mathbf{2 0 1 1}$ & $\mathbf{2 0 1 2}$ & $\mathbf{2 0 1 3}$ & $\mathbf{2 0 1 4}$ & $\mathbf{2 0 1 5}$ \\
\hline $\begin{array}{c}\text { Imposed prison sentences for the } \\
\text { offences against animals }\end{array}$ & 11 & 10 & 6 & 9 & 30 & 23 \\
\hline $\begin{array}{c}\text { Imposed prison sentences for animal } \\
\text { killing and abuse offences }\end{array}$ & 0 & 1 & 1 & 5 & 6 & 1 \\
\hline
\end{tabular}

Souces: Bilten broj 578, 588, 603, 617 Republički zavod za statistiku, Beograd, Republika Srbija. ISSN 0354-3641.(eg.l. Bulletin No. 578, 588, 603, 617. The Republic Statistical Office).

On the basis of the results of the research arising from the Table 4, it can be noticed that out of the total number of the accused persons for the offence of animal abuse and killing, the prison sentence was imposed against 12 person which makes $7 \%$ of the number of the suspected adult persons.

Table 4. The finding on the amount of criminal sanctions of the persons for the offences against animals (prison sentence)

\begin{tabular}{|c|c|c|c|c|c|c|}
\hline \multirow{2}{*}{ Sample of research } & \multicolumn{5}{|c|}{ Years of the sampled sample } \\
\cline { 2 - 7 } & $\mathbf{6}$-3 years & $\begin{array}{c}\mathbf{1 - 2} \\
\text { years }\end{array}$ & $\begin{array}{c}\mathbf{6 - 1 2} \\
\text { months }\end{array}$ & $\begin{array}{c}\mathbf{3 - 6} \\
\text { months }\end{array}$ & $\begin{array}{c}\mathbf{2 - 3} \\
\text { months }\end{array}$ & $\begin{array}{c}\mathbf{1 - 2} \\
\text { months }\end{array}$ \\
\cline { 2 - 7 } & 0 & 0 & 1 & 4 & 4 & 3 \\
\hline $\begin{array}{c}\text { Killing and abuse of } \\
\text { animals }\end{array}$ & 0 & 0 & 1 & 1 & 1 & 0 \\
\hline $\begin{array}{c}\text { Transmission of the } \\
\text { infectious disease to } \\
\text { animals and plants }\end{array}$ & 0 & 0 & 0 & 0 & 0 & 0 \\
\hline Veterinary malpractice & 0 & 0 & 0 & 0 & 0 & 0 \\
\hline $\begin{array}{c}\text { Production of the harmful } \\
\text { agents for animal treatment }\end{array}$ & 0 & 0 & 0 & 1 & 0 & 0 \\
\hline $\begin{array}{c}\text { Pollution of water and food } \\
\text { for animals }\end{array}$ & 1 & 1 & 3 & 6 & 8 & 1 \\
\hline Illegal hunting & 0 & 0 & 2 & 8 & 13 & 11 \\
\hline Illegal fishing & & 0 & & & 0 \\
\hline
\end{tabular}

Sources: Bilten broj 578, 588, 603, 617 Republički zavod za statistiku, Beograd, Republika Srbija. ISSN 0354-3641.(eg.1. Bulletin No. 578, 588, 603, 617. The Republic Statistical Office). 
When we analyze the results over the research period from the Table 4, we conclude that out of the total number of the imposed prison sentences, in the greatest number of cases the two or three months prison sentence was imposed, while only in one case the person was sentenced for six to twelve months in prison.

\section{Conclusion}

The outcome of the research indicates that the animal protection in the Republic of Serbia has been more concretely standardized at the beginning of this century within general and specific legal protection. When the findings from the research are analyzed, it can be spotted that there is a negative correlation between formally and legally standardized animal protection and the way how it is exercised in the field. It has been found that there are a high percentage of dismissed criminal charges, low percentage of convictions as well as an inadequate structure of the imposed criminal sanctions. This indicates a necessity for a change in criminal policy in the field of animal protection and exercising their welfare.

From the results which were received through the application of the scientific legal and dogmatic methods, the analysis of the content, description, qualitative and quantitative correlation a few findings was obtained. The first finding shows that contemporary legal theory and legislation of Serbia do not deny the right to animal protection.

The second finding refers to the fact that within the codification of the substantive criminal law of the Republic of Serbia which was preformed in 2005, the offences which provide legal protection of animals did not receive significant importance, at the first place, since they were not standardized within an independent chapter of the Criminal Code, but were included in the chapter which relate to environmental protection.

The third finding determines that a total of seven criminal offences, classified into four groups according to the object of legal protection, was classified and described under the environmental offences.

The forth finding indicates that the legal animal protection is dispersed and laid down by several legal acts/laws.

The fifth finding of the research results indicates that the Constitution as the highest law does not recognize specifically prescribed legal obligation to protect animals. The sixth finding shows a high percentage of loss of crime in the criminal offences against life and physical integrity of animals. The seventh fining proves the existence of an extremely law rate in the number of convicted adult persons for committing criminal acts against animals in the Republic of Serbia. In the eight finding the difference between proclaimed right to animal protection according to the rules prescribed by law in the Republic of Serbia and achieving de facto protection of animals in the field. 


\section{References}

1. Baumans, V.(2004). Use of animals in experimental research: an ethical dilemma? Review Gene Therapy, Stockholm, 11, S64-S66.

2. Beirne, P. (2004). From Animal Abuse to Interhuman Violence? A Critical Review of the Progression Thesis, Society and Animals - Journal of Humane - Animal Studies, Leiden, 49.

3. Bilten broj 578,588. (2014). Republički zavod za statistiku, Beograd, ISSN 03543641. (eng. l. Bulletin number 578, 588 (2014). Republican Bureau of Statistics, Belgrade).

4. Bilten broj 603. (2015). Republički zavod za statistiku, Beograd, ISSN 0354-3641. (eng. l. Bulletin number 603. (2015). Republican Bureau of Statistics, Belgrade).

5. Bilten broj 617. (2016). Republički zavod za statistiku, Beograd, ISSN 0354-3641. (eng. l. Bulletin no. 617. Republican Bureau of Statistics, Belgrade.

6. Blessing, J., Marshall, J., Balcombe, S.(2010). Humane killing of fishes for scientific research: a comparison of two methods Journal of Fish Biology, Volume 76, Issue 10, 2571-2577.

7. Broom, D. (1991). Animal welfare: Concepts and measurement. Anim. J., Cambridge Vol.16: 4167-4175.

8. Camm, T., Bowles, D.(2000). Animal welfare and the treaty of Rome - legal analysis of the protocol on animal welfare and welfare standards in the European Union, Journal of Environmental Law, Volume 12, Issue 2, 197-205.

9. Carenzi, C., Verga, M. (2007). Animal welfare: Review of the scientific concept and definition, Scientific Association of Animal Poduction, pp. 25, by source: Hughes, B. O. (1976). Behaviour as index of welfare,1005-1018 in Proc. 5th Eur. Poultry Conf., Malta.

10. Encyclopaedia of the social sciences, Macmillan Co., New York, Volume XIII, 1933, 531.

11. Feinberg, J. (2012). Ethical Theory: An Anthology, The rights of animals and unborn generations.Second Edition, Edited by Russ Shafer-Landau, WileyBackwell.ISBN 978-0.470-761160-3.

12. Huss Rebecca, J. (2004). Valuation in Veterinary Malpractice. Loyola University Chicago Law Journal, Chicago, Vol. 35, No. 2, 2004.

13. Lazarević, Lj. (2006). Komentar krivičnog zakonika Republike Srbije, Savremena administracija, Beograd, 695.

14. Mason, G., Latham, N. (2004). Animal Welfare, Can't stop, won't stop: is stereotypy a reliable animal welfare indicator? Vol 13 (Suppl), S57-S69.

15. McGrath, J., Drummond, G., McLachlan, E., Kilkenn, and Wainwright, C. (2010). Guidelines for reporting experiments involving animals: the ARRIVE guidelines, British Journal Pharmacological, UK, Volume 160, Issue 7, 1573-1576.

16. Nielsen, K. (2001). Animal Evolution: Interrelationships of the Living Phyla (2nd edition). Oxford University Press. 
17. Petrović, M., Simić, I. (1085).Praktična primena Krivičnog zakona Republike Srbije, "Napredak", Aranđelovac, 174.

18. Rollin, B. (1993). Animal welfare, science and value. Journal of Agricultural and Environmental Ethics. Printed in the Netherland, Vol. 6: 44-50, ISSN:1187-7863.

19. Srzentić, N., Lazarević, Lj., Đorđević, M., Stajić, A., i Kraus, B. (1991). Komentar Krivičnog zakona Republike Srbije, Savremena adminstracija, Beograd, 444-445.

20. Sutherlandu, H., Cressey, R., Luckenbill, F. (1992). Principles of Criminology, eleventh edition, Maryland, ISBN 0-930390-69-5.

21. Webster, J. (2006). Animal sentience and animal welfare: What is it to them and what is it to us? Appl. Anim. Behav.100: 1. Volume 100, Issues 1-2, Langford, p. 1-3.

22. Directive 86/609/EEC - J. Eur. Commun. Legal Spec. (1986). Reconciliation of Legal and Administrative Regulations of the Member Countries for the Protection of Animals used for Studies. Directive 86/609/EEC - J. Eur. Commun. Legal Spec., 1986.

23. Krivični zakonik (2013). (“Službeni glasnik RS”, br. 85/2005, 88/2005, 107/2005, 72/2009, 111/2009, 121/2012 и 104/2013), Beograd. (eng. L.Criminal Code (2013). ("Official Gazette of the Republic of Serbia", No. 85/2005, 88/2005, 107/2005, 72/2009, 111/2009, 121/2012 and 104/2013), Belgrade.)

24. Pravilnik o uslovima dobrobiti životinja u smislu prostora za životinje, prostorije i opremu u objektima u kojima se čuvaju i uzgajaju životinje koje se stavljaju u promet za proizvodne svrhe, način držanja, odvođenja i transporta odreženih životinjskih vrsta i kategorija, kao i vođenje evidencije životinja (2014). ("Službeni glasnik RS", br. 6/2010 и 57/2014), Beograd. (eng. 1. Rulebook on animal welfare conditions in terms of space for animals, premises and equipment in facilities in which animals are placed and marketed for production purposes, the manner of keeping, transporting and transporting animal species and categories as well as keeping records of animals (2014), («Official Gazette of the Republic of Serbia», No. 6/2010 and 57/2014), Belgrade.)

25. Pravilnik o proglašenju i zaštiti strogo zaštićenih divljih vrsta biljaka, životinja i gljiva (2010). ("Službeni glasnik RS", br. 5/2010), Izvod iz Aneksa I i Aneksa II, Beograd. (eng. 1. Ordinance on the designation and protection of strictly protected wild species of plants, animals and fungi (2010). ("Official Gazette of the Republic of Serbia", No. 5/2010), Excerpt from Annex I and Annex II, Belgrade).

26. Ustav Republike Srbije (2006). ("Službeni glasnik RS", br. 98/2006), Beograd, Srbija. (eng. 1. Constitution of the Republic of Serbia (2006). ("Official Gazette of the Republic of Serbia”, No. 98/2006), Belgrade, Serbia).

27. Zakon o zaštiti životne sredine (2009). ("Službeni glasnik RS”, br. 135/2004, 36/2009, 36/2009 - dr. Zakon 72/2009 - dr. Zakon i 43/2011. - Odluka Ustavnog suda), Beograd. (eng. 1. Law on Environmental Protection (2009). ("Official Gazette of the Republic of Serbia", No. 135/2004, 36/2009, 36/2009 - other Law 72/2009 - other Law and 43/2011 - Decision of the Constitutional Court), Belgrade. 
28. Zakon o trgovini (2010). (,Službeni glasnik RS“, br. 53/2010 i 10/2013), Beograd. (egl. 1. Law on Trade (2010). ("Official Gazette of the Republic of Serbia”, No. 53/2010 and 10/2013) Belgrade.

29. Zakon o lovstvu (2010). („Službeni glasnik RS“, br. 18/2010) Beograd, Srbija. (egl. L. Law on Hunting (2010). ("Official Gazette of the Republic of Serbia", No. 18/2010) Belgrade.

\title{
ŽIVOTNA SREDINA I PRAVNA ZAŠTITA ŽIVOTINJA U REPUBLICI SRBIJI
}

\author{
Zdravko Petrovic ${ }^{4}$, Jović Vojislav ${ }^{5}$, Manojlović Dragan $^{6}$
}

\begin{abstract}
Sažetak
Cilj ovog rada je bio da se primenom naučnih metoda istraži zaštita životinja u pravnoj legislativi Republike Srbije, kroz delikte o životnoj sredini. Iz rezultata istraživanja dobijenih primenom naučnih metoda pravno dogmatske, analize sadržaja, kvantitative, kvalitativne i korelacije, izvodi se nekoliko nalaza koji pokazuju da: u savremenoj pravnoj teoriji i zakonodavstvu Srbije se ne poriče pravo na zaštitu životinja, u okviru kodifikacije materijalnog krivičnog zakonodavstva Republike Srbije koja je izvršena 2005. godine. Krivično-pravne norme kojima se pruža pravna zaštita životinja nisu dobili na svom značaju, pre svega zbog njihovog normiranja u okviru ekoloških delikata, a ne u okviru samostalne glave krivičnog zakonika što bi bilo opravdano. Delikti protiv životinja svrstani su u glavu krivičnih dela kojima se štiti životna sredina u okviru sedam krivičnih dela, podeljenih u četiri grupe u zavisnosti od objekta pravne zaštite. Pravna zaštita životinja je disperzirana i propisana u nekoliko pravnih akata-zakona. Najviši pravni akt Ustav ne poznaje posebno propisanu obavezu zaštite životinja. Vremenski $i$ prostorno određeno empirijsko istraživanje obuhvata osmogodišnji period na prostoru Republike Srbije, po parametrima koji se odnose na broj prijavljenih, optuženih $i$ osuđenih punoletnih lica za krivična dela protiv životinja. Rezultati istraživanja u ovom radu ukazuju na negativnu korelaciju između broja podnetih krivičnih prijava protiv počinioca, podignutih optužnica i izrečenih presuda za krivična dela: napad na život, telesni integritet $i$ dobrobit životinja.
\end{abstract}

Ključne reči: ekološka zaštita, životinje, krivični delikti, sankcije i prestupnik.

4 Zdravko Petrović, PhD., redovni profesor, Pravni fakultet, Bulevar umetnosti br. 29, 11070 Novi Beograd, Srbija, tel.:+381 63575 880, E-mail:zpetrovic@megatrend.edu.rs

5 Vojislav Jović, PhD., docent, Pravni fakultet, Bulevar umetnosti br. 29, Novi Beograd, Serbija, tel.: +381 6313339 99, E-mail: vjovicbg@gmail.com

6 Dragan Manojlović. PhD., redovni profesor, Pravni fakultet, Bulevar umetnosti br. 29, Novi Beograd, Serbija, tel.:+ 3816432219 26, E-mail:savaskela@gmail.com

EP 2018 (65) 1 (293-305) 